\title{
Corporate Social Responsibilities (CSR) and Empirical Insight into CSR Practises of Companies Listed on the BIST 100
}

\author{
Melih SÖNMEZ iD a \\ a Erzincan Binali Yıldırım University, Faculty of Law, Turkey. melihsonmez@erzincan.edu.tr
}

ARTICLE INFO
Keywords:
Corporate Social
Responsibility
Advantages and The Side
Effects
Practicability of the CSR

Received 2 September 2021 Revised 1 December 2021 Accepted 15 December 2021

Article Classification: Research Article

\section{ABSTRACT}

Purpose - The main aim of this study is to evaluate the role, importance, advantages and disadvantages of CSR and to understand to what extent the theory of CSR has been converted into the practice in companies listed on the BIST 100.

Design/methodology/approach - This study is based on combination of qualitative and quantitative approaches. Fundamentally, it can be divided into two parts. The first part provides a theoretical framework for the main issues of CSR. In this respect, the first part of the study uses library-based information, such as books, articles and web-sources. The second part analyses the practicability of these theories by making an empirical research about CSR practises of companies listed on the BIST 100. The sample size of this study consists of randomly selected 30 companies that are carried out their commercial activities within the different sectors. All information used throughout this study is primary and indicates the 2020/2021 data of these companies on their annual reports or webpages. The BIST 100 is accepted as the main indicator used to measure the market and volume performance of the top 100 shares traded in the BIST. It is an index that is carefully examined by all major investors. The fluctuation expectations of the stock market are made by taking into account the BIST 100 Index. Briefly, the shares of these 100 corporations reflect the overall performance of the BIST. Hence, in order to get more realistic results about the success of corporations on disclosing level of CSR, the BIST 100 Index has been applied in this research.

Findings - The finding of this study showed that the CSR helps to increase the number of long-term investors in financial markets, to improve the quality of products and services in corporations, and to reduce social, environmental, ethical problems in society. Due to these advantages of the CSR, the empirical research also proved that the application process of the CSR projects seems to reach a satisfactory level for listed companies on the BIST 100 on a voluntary basis. However, the points to take into consideration are the availability of human rights and anti-corruption issues because this type of the CSR projects seems to be problematic for the selected corporations. Additionally, it can be useful to create a competent authority, which will be responsible for monitoring and supervising all the CSR projects.

Discussion - When CSR is examined in the first place; it can be seen as a new burden that increases the costs for corporations. Additionally, defenders of the traditional economics theory accept CSR as violating obligation to shareholders and covering the wrongdoings of corporations. Yet, it also provides many advantages in terms of companies, financial markets and societies. The most important benefits of CSR can be listed as follows; it may increase the number of both national and international investors; thus, it makes positive contributions to the long-term profitability of a company; it may improve the quality of products, the brand value and competitive power of corporations by having a positive impact on the performance of employees; it also helps to protect environment, to care human-rights issues and to establish good relations with non-governmental organizations. 


\section{Introduction}

It can be fairly said that all corporations have a single goal in the financial markets, which is profit. Hence, maximizing the profits plays a key role in every action taken by corporations. However, a corporation should be also held responsible to the society, as well as to its shareholders. These social expectations from the corporate behaviour have created the concept of corporate social responsibility. Although there is still no common definition accepted all over the world, CSR can be simply defined as an idea that corporations carry out social and environmental concerns in their activities and in interactions with their stakeholders.

In general CSR can be accepted as the sense of responsibility that corporations should have in order to make positive contributions to society. It is a process of providing non-financial information with regard to environmental, ethical, philanthropic and economical responsibilities. In this respect, CSR also plays a key role in improving the transparency level of both financial markets and corporations. Transparency, as the XRay of the markets, helps to create an atmosphere of mutual trust between the market players. It aims to minimize the risks that investors may face by making essential information available in the right place and at the right time. The basis of transparency is based on sharing true information in the markets. Briefly as the sunshine of the markets, transparency unveils the dark side of corporations and all players.

Information that plays a key role in the decision-making process of investors is subject to a dual classification: "Financial information and Non-financial information". Financial information gives detailed information about the economic performance of corporations, such as profits, losses or assets. Non-financial information covers environmental issues, social and employee perspectives of corporations, human-rights practices, anti corruption and bribery issues and the board diversity (Directive 2014/95/EU of the European Parliament and of the Council (6)). In this respect, non-financial transparency consists of the CSR policies.

CSR is a controversy issue in the literature. For example according to Friedman, CSR cannot be highlighted as a moral activity, because it is simply stealing from the owners of corporations (Friedman, 1970). He believes that corporations are not charity; therefore, resources of corporations should not be used for non-business issues. Secondly, due to its positive impact on the attractiveness of corporations, CSR can be used to hide the devil side of corporations. In this respect, CSR can be perceived as covering wrongdoing of corporations (Ormiston and Wong, 2013). Thirdly, CSR can lead to a separation between making profits and social, environmental and ethical issues (Harris and Freeman, 2008: 541-543). And fourthly, CSR may not be extended towards corporations due to its costs in markets, where there is a high level of competition (Campbell, 2007: 950-954).

However, despite all these debates, CSR may also has some positive impacts on financial markets, corporations and society itself. For instance, it may increase the number of long-term investors in financial markets, improve the quality of products and services in corporations, and help to reduce social, environmental, ethical problems in society.

This study aims to explore the role, importance, advantages, side effects and potential problems of CSR for market players and to understand to what extent the theory of CSR has been converted into the practice in companies listed on the BIST 100. In this respect, the first part of the study creates a conceptual theoretical framework about the main mission of CSR for all market players. The second part evaluates the applicability level of CSR into the practise by making an empirical research on companies listed on the BIST 100.

\section{Literature Review}

\subsection{What is CSR?}

In the business and financial world, historically making money and maximising shareholders value have been accepted as the main driving force for corporations. However, the way of achieving this main goal in the business world had many negative effects in the real world. Therefore, these irresponsible behaviours of corporations have initiated to change the approaches of investors towards corporations. In this respect, today's new key elements in the business world can be accepted as corporate sensitivities for the environment, working conditions, ethical practices and social issues. In other words, it can be claimed that in today's business world, just focusing on the shareholder maximisation in corporations will not be tolerated by the society (Jhawar/Gupta, 2017: 105). 
CSR can be taken into account as the new driving force in the business world and be simply defined as the long-term projects of corporations for their positive contributions to environmental and social issues while performing their commercial activities. It basically provides non-financial transparency about approaches of corporations regarding ethical values, working conditions, environmental and social issues. However, it may not easy to make a generally accepted definition, because social responsibility behaviours may vary according to field of corporations or the perspectives of parties (Campbell, 2007: 950). Therefore, the definition should focus on the relations between corporations, governments, non-governmental organizations and society.

In order to create a better understanding about CSR, numerous attempts have been done so far in the literature (Kağnicioglu, 2007: 126; Koroglu/Ersoz, 2015: 130; Carroll, 2015: 89; Jarolimek, 2016: 132). For example, European Commission highlights CSR as an investment on human capital, the environmental and social issues, and the relations with stakeholders (European Commission, 2001). According to World Business Council for Sustainable Development (WBCSD), CSR is an obligation for corporations to contribute sustainable economic development in financial markets by providing benefits to employees, families, local communities and society (WBCSD, 1999: 10;). Kotler and Lee defines it as an obligation that will cover psychological needs as well as welfare, health and safety for the social welfare with the contributions of voluntary practices and business resources (Kotler/Lee, 2017: 201). In this respect, it may not wrong to say that CSR is the sense of responsibility that corporations should have in order to indicate their sensitivity towards environmental and social issues.

In the light of these definitions, the common responsibilities of corporations can be listed as follows (Akmeşe, 2017: 11-12):

- Corporations, beyond making profits with the production of goods and services, are responsible not only to their shareholders, but also to all stakeholders, society and environment;

- Corporations have responsibilities to contribute making solutions for the social and environmental problems arising from their commercial activities;

- In addition to focusing on economic and financial values, corporations should also serve social values in a border sense.

The question that needs to be asked in here however is why corporations have such a broad responsibility regarding the social and environmental issues. It can be claimed that in order to preserve their existence in the competitive markets, it is basically about the fulfilment of the essential social efforts towards to society to which they are indebted. The recent studies have indicated that CSR has some positive impacts on the attractiveness of corporations in the financial markets (Dalyan/Gökbel, 2005: 5; Fisk, 2010: 32; Öztürk, 2013: 38). In other words, corporations are no longer evaluated according to their financial performance; their intangible values, such as reputation, honesty, transparency, sensitivity and helpfulness have started to play a key role in the decision-making process of investors. Hence, making profits and maximisation of shareholders values, which is the main aim $\mathrm{f}$ corporations, depends on the success of CSR policies of corporations. In the following parts, the main advantages and side effects of CSR will be deeply examined.

\subsection{Advantages of CSR}

The effect of globalization leads to a worldwide change in the economic structure of markets and consumers' preferences by increasing competitive environment. The fact that consumers are more conscious and sensitive in these renewed markets, CSR has become more important in the corporate dimension. In addition to consumers' choices, some international agreements, such as the Convention on Human Rights (1964), the Convention on International Environmental Policy (1972) or the Kyoto Protocol (1997) also played an important role in the development process of CSR. Therefore, corporations need to focus on social responsibility activities in order to gain legitimacy in the society and to show that they are socially responsible citizens (Tak, 2009: 149). In fact, CSR activities can be seen as burdensome for corporations, they can provide some advantages in financial markets.

First of all, there are some studies in the literature, which highlight a strong correlation between the environmental and social policies and the financial performance of corporations (Saxton, 1998: 393-395; 
Robert/Dowling, 2002: 1081-1085; Kitzmueller/Shimshack, 2012: 70). Therefore, one of the advantages of CSR is to have a positive impact on increasing the profitability of corporations.

Secondly, CSR helps to support marketing goals and to improve brand image of corporations by creating a social impact (Kotler/Lee, 2017: 140) and providing prestige awards. It can be seen that corporations have been recently rewarded by various organizations and institutions for their contribution to the economic and social purposes, which has also indirectly improved the corporate image in terms of all interested parties in corporations. Today, various organizations in the world are making efforts to spread and institutionalize the CSR activities. In this respect, be listed in Fortune Magazine World's Most Admired Companies or Business Ethics' 100 Best Corporate Citizens, can be accepted as a prestige award that has a positive impact on the attractiveness of corporations in financial markets (Hoştut and Deren Van Het Hof, 2014: 2-3; Van Riel/Fombrun, 2003: 246; Ersöz, 2009: 138). Additionally, the existence of these Non-Governmental Organizations (NGOs), such as OECD or Global Reporting Initiative (GRI), also puts pressure on both governments and corporations to spread corporate social responsibility projects (Taşliyan, 2012: 23). Thus, CSR can be accepted as a natural assurance for the commercial activities.

Thirdly, CSR also plays an important role in the securities markets. With social reporting, corporations have the opportunity to disclose the results of their social performance to their stakeholders, such as investors or customers; so, this increases the share values, market values and brand values of corporations respectively (Demirtaş, 2015: 46).

Fourthly, it may have positive effects on corporate image and employee motivation (Kağnıcıŏlu, 2009: 126). Fundamentally, creating the perception of a socially responsible corporation in the eyes of market players may constitute a good example in both national and international arena. This perception may lead to dual advantages for corporations. At first, it can be highlighted that a solid reputation in society can constitute real wealth in times of crises (Kotler/Lee, 2017: 15). This reputation helps to create trust and loyalty against corporations (Demirtaş, 2015: 3). Hence, socially responsible corporations will gain the competitive advantages in the market. Secondly, it can be emphasized that there is a strong correlation between employee motivation and the corporate image. Employee motivation improves the quality of products that are produced in corporations, which positively affects the brand and corporate image.

And fifthly, CSR helps to create a better financial environment based on the principle of goodwill, which provides stakeholders' support and increases trust in the markets. The main benefit of this environment is that it ends the speculative investment approach and makes corporations more attractive for the long-term investors (Aydinalp, 2013: 3).

In the light of these advantages it can be claimed that an effective CSR project primarily provides more sensitive approach to environmental and social issues in the markets. By creating a work atmosphere that respects human rights, helps to improve working conditions in corporations. It increases awareness on environmental issues, such as greenhouse gas emissions, pollution and unconscious destruction of natural sources. In addition to social and environmental benefits, it contributes to increase the number of long-term of investors for corporations by building trust between the market players. Hence, it is ensured that financial markets work effectively in a reliable environment and sensitive to social and environmental issues. On the other hand, CSR may also lead to some side effects or disadvantages for corporations. In the following part, these potential drawbacks of CSR will be briefly examined and evaluated.

\subsection{The Side Effects of CSR}

The idea of CSR, besides its advantages, has also some disadvantages for corporations. In this respect, due to these difficulties, assuming CSR projects to become widespread by all companies in the market will not go beyond a well-intentioned expectation. These negative impacts of CSR can be listed as follows (Campbell, 2007: 950-954):

Firstly, the costs of the CSR projects can take the leading position for the main disadvantage of CSR. As mentioned before, corporations are generally economic entities that aim to maximize profits in the commercial life. Hence, like charities, their fundamental policies cannot be based on establishing social awareness projects (Hetherington, 1973: 37 cited in Crowther/Aras, 2008:12). Additionally, in the competitive market, corporations generally try to decrease their costs. However, implementation and disclosing of such CSR 
projects in the financial statements will cause additional costs. Therefore, due to the costs of the CSR projects, it may not be preferred and applied by all corporations.

Secondly, the structure of markets also plays an important role in the effective implementation of such projects. In other words, it may not be easy to develop the CSR projects in markets, where competition is very low. In the markets where there is a little competition or no competition, such as monopoly markets, because there are no other options for consumers or investors, corporations do not need to make a great effort to become attractive in the markets. Therefore, the competitive structure of the markets is also important for the sensitivity of the CSR projects.

Thirdly, according to Friedman, the CSR projects simply violate shareholders' rights in corporations (Friedman, 1970). He accepts CSR as an "immoral activity", because he believes that spending corporate resources for social and environmental issues (non-business activities) is like extorting money from shareholders (Freeman/Dmytriyev, 2017: 7). If shareholders want, they can privately contribute to the social and environmental projects. However, corporations should not be forced to apply for the CSR projects for their business activities, as they are not charities (Friedman, 1970).

Fourthly, it can be seen that recently, even some well-known corporations, such as Coca Cola, Primark, BP, Philip Morris, Lokheed and Caterpillar have led to environmental and social damages in all around the world (Boeger, Murray and Villiers, 2008: 86). In the last two decades, environmental pollution has reached unbearable levels, the uncontrolled greenhouses gas emission has caused to climate change and global warming, human rights have been violated many times with examples such child labour, and health and safety issues in business environment have not been provided in an effective manner. This devil side of corporations has led to decrease their reputation between the market players. In this respect, the CSR projects can only be applied by corporations to cover their wrongdoings (Freeman/Dmytriyev, 2013). In addition, this perception may also create a misleading believe about CSR. Due to this false feeling, the society may assume that corporations only implement the CSR projects if they have a negative impact on the social or environmental issues (Ormiston/Wong, 2013).

And finally, there are some criticisms about CSR in the literature for leading to a distinction between making profits and social, environmental and ethical issues (Freeman/Dmytriyev, 2013). Fundamentally, it can be claimed that the long-term success of commercial practices depends on the harmony between the aim of making profits and the sensitivity towards the social and environmental issues. Therefore, corporations can also serve the society while carrying out the commercial activities.

\subsection{Dimensions of CSR}

Throughout the history, the concept of CSR has been discussed in different dimensions by different scholars in accordance with the changes and developments experienced in the society, market structure and corporations. For example, Davis stated that corporations could only survive by primarily carrying out the needs of the society apart from their economic and technical interests (Davis, 1960: 76). On the other hand, as mentioned above, according to Friedman, corporations do not have corporate responsibility, because responsibility is an individual concept that can be done in accordance with the inner conscious of shareholders (Friedman, 2007: 178).

In this respect in 1979, Carroll aimed to integrate all these different views on social responsibility and developed a model to reveal the dimensions of CSR (Carroll, 1979: 504). With this model, he tried to classify the thoughts of managers on social issues in order to increase their impacts on social problems. In 1991, Carroll in his later work improved this model in accordance with the application areas of CSR and created the pyramid of CRS (Carroll, 1991: 42). According to him, corporations have four basic responsibilities as "economic, legal, moral and philanthropic", which must be fulfilled at the same time (Carroll, 1991: 42).

Economic power can be accepted as the foundation of all other responsibilities, because it can be claimed that other responsibilities are based on the existence of the economic responsibility. It basically refers to the main aim of corporations, which is maximizing the profits and improving and maintaining the competitive powers in the financial markets (Vural/Coşkun, 2011: 72). Carrying out the economic responsibility leads to a chain reaction on the pyramid of CSR. Therefore, according to Carroll, the economic responsibility has a pioneering impact on the legal, moral and philanthropic responsibilities (Carroll, 1991: 42). These four categories of 
responsibilities reflect the existence and the main mission of corporations in society. In this respect making an effort in increasing profits, obeying the law, participating in the ethical practices and being a good corporate citizen, represent the whole pyramid of CSR.

The legal responsibility simply refers to the expectation on carrying out to the commercial activities of corporations in accordance with the local, regional, national and international regulations (Ersöz, 2009: 136). It is mainly provided through various indicators, including laws that regulate competition in general, protect the consumer and the environment, and provide equality and trust (Özgener, 2000: 169). Therefore, corporations should fulfil their economic responsibility within the framework of these regulations determined by the laws (Carroll, 1991: 42).

The moral responsibility specifies the rules that are expected to follow and the duties to be performed in human relations. It is basically a requirement of being an individual in society. In terms of commercial activities, corporations have also various moral responsibilities in economic, social, political and ecological terms (Aktan, 2011: 68-70). The moral dimension of CSR is expressed as conducting the commercial activities in accordance with the ethical principles, which are in line with the expectations of society from all undertakings (Carroll, 2016: 3). In this respect, the ways and methods chosen by corporations in achieving their goals should be carried out within the framework of moral judgments without having a negative impact on the political, economic, social and cultural welfare of the society (Akmeşe, 2017: 33). According to Carroll, the moral responsibilities can be listed as follows (Carroll, 1991: 41); acting in accordance with the social and moral norms; recognizing and respecting the new or evolving moral norms adopted by society; considering the moral norms in achieving the corporate goals; being a good corporate citizen by fulfilling the moral expectations; and recognizing that honesty and ethical behaviour as important as complying with laws and regulations. Corporations are obliged to fulfil their duties and responsibilities towards the environment and society within the scope of business ethics (Aktan/Börü, 2007: 13). Therefore, all undertakings should take into account the basic obligations of honesty, fairness and righteousness, and should abstain from damaging the rights of their stakeholders (Carroll, 1991: 44).

From an institutional point of view, the philanthropic responsibility can be defined as the liability of undertakings to the society due to their existence. In other words, all undertakings have an obligation to protect the general interest of the society to which they owe their existence, and to act sensitively to the fundamental problems of the society (Peltekoğlu, 2014: 190). This responsibility covers the corporate actions that respond to society's expectations as good corporate citizens and includes all the actions that have a positive impact on the public welfare (Carroll, 1991: 44). In this respect, this responsibility refers to the contributions of undertakings to the society without a legal obligation or moral expectation. Although the philanthropic responsibility is on a voluntary basis, it strengths the attractiveness of corporations in the financial markets and contributes to the perception of undertakings as a good corporate citizen. However, it is important to highlight in here that the main aim of carrying out philanthropic practises is to benefit society rather than to benefit the commercial activities of undertakings (Akmeşe, 2017: 33).

\subsection{Types of CSR}

It can be claimed that the changing social structure and expectations of the society may put pressure on undertakings to fulfil their social responsibilities in different fields with the different practices. In particular, the development of some concepts, such as social welfare, social justice or corporate citizenship leads to an enlightenment on undertakings' strategies in terms of environmental issues, social and moral principles, and relations with all their stakeholders while performing their commercial activities. The question that needs to be asked in here however is what kind of activities can be accepted as the CSR projects?

There is a large volume of published studies describing the types of CSR activities in the literature. For example, Hohnen explains the area of the CSR activities by considering the view of World Business Council for Sustainable Development and listed as follows (Hohnen, 2007: 4-5):

- Corporate governance and ethics,

- Health and safety,

- Environmental management,

- Human rights, 
- Sustainable development,

- Working conditions,

- Industrial relations,

- Social participation, development and investment,

- Respect to different cultures and people with disabilities,

- Corporate philanthropy and employee volunteering,

- Costumer satisfaction and fair competition,

- Anti bribery and anti corruption measures,

- Reporting of accountability, transparency and performance,

- Relations with national and international supply chains.

Bonsu has limited the implementation of CSR on three main areas; employees, customers and society in general (Bonsu, 2019: 14). According to him, welfare of employees, violation of human rights issues, health and safety measures, and education and learning process should be considered for employees; in terms of customers, high quality in products and services, sensitivity on environmental issues and maximum costumer satisfaction should be provided; and for the society, donations and aids should be increased in some areas, such as health, natural disaster, environmental pollution and poverty.

Last but not least, Directive 2014/95/EU on disclosing of non-financial information also plays a key role in indicating which types of the CSR projects are classified in a legislative framework. It can be claimed that the main purpose of Directive 2014/95/EU is to improve the transparency level of a certain large undertakings and groups in the EU in terms of non-financial information that will be useful in the decision-making process of investors. In this respect, Directive 2014/95/EU categorises types of the CSR projects under the three main areas: "Environmental Matters, Information on Employees and Social Issues and Information on Human Rights and Anti-Corruption Issues" (Gardner and Lienin, 2015). According to the preliminary provisions of the Directive; information on environmental impacts, health and safety impacts, renewable and non-renewable energy use, greenhouse gas emission, water use and air pollution should be prepared under the environmental matters; information on ensuring gender equality, implementation of fundamental ILO conventions, working conditions, health and safety at work, social dialogue, worker information and consultation, respecting trade union rights and local community dialogue should be prepared under the employee-related matters; and information on the prevention of human rights abuses and in place to fight against corruption and bribery should be prepared under the information on human rights and anti corruption issues (Directive 2014/95/EUPreliminary Provisions/7).

\section{Empirical Insight into the Non-Financial Transparency Practises of Companies Listed on the BIST 100}

As seen above, in the first part of the study, the role, importance, advantages, side effects and potential problems of CSR for market players have been discussed. The finding of the first part indicates that despite the minor side effects, CSR has positive impacts on the decision-making process of investors and all stakeholders.

From this point of view, an empirical research can be useful to understand to what extent the CSR projects have been implemented by companies listed on the BIST 100. The research will be based on the availability of three types of information (Environmental Matters, Information on Employees and Social Issues and Information on Human Rights and Anti-Corruption Issues) as explained in Directive 2014/95/EU-Preliminary Provisions/7. The reason of making an empirical research in Turkey is that there is no legal regulation regarding the CSR projects in Turkey. Therefore, it can be said that disclosing the non-financial information and applying the CSR projects in Turkey is based on a voluntary-basis. In this respect, this research aims to examine the implementation level of the CSR projects even if there is no any legal requirement in the legislative framework.

\subsection{Structure of Hypotheses}

This part intends to explore whether the selected companies on the BIST 100 managed to apply the abovementioned any types of the CSR projects for their stakeholders.

Results are indicated in a tabular form below and indicated with a 'box ticking style'. Symbols ' $\checkmark$ ' and ' $\mathbf{x}$ ' were 
assigned to the three areas of the CSR projects for each of the thirty selected companies. Here, ' $\mathbf{x}$ ' refers to 'no availability' of the CSR projects and ' $\checkmark$ ' refers to 'availability' of the CSR projects in the annual report or webpages of companies.

\subsection{Sample Selection}

The sample size of this work will be created by choosing thirty firms from among listed companies on the BIST 100. In order to strengthen and to obtain more effective results from this empirical research, the selection will be determined randomly from different sectors. In particular, this selection will be done among companies those have a potential negative impact on the environment or society while carrying out their commercial activities. These companies can be listed as follows (KAP, BIST 100):

1) Anadolu Efes Biracılık ve Malt Sanayi AŞ; 2) Brisa Bridgestone Sabancı Lastik Sanayi ve Ticaret AŞ; 3) Coca Cola İçecek AŞ; 4) Çan2 Termik AŞ; 5) Çimsa Çimento Sanayi ve Ticaret AŞ; 6) Enka İnşaat ve Sanayi AŞ; 7) Ereğli Demir Çelik Fabrikaları TAŞ; 8) Gübre Fabrikaları TAŞ; 9) İskenderun Demir Çelik AŞ; 10) Koç Holding AŞ; 11) Koza Altın İşletmeleri AŞ; 12) Mavi Giyim Sanayi ve Ticaret AŞ; 13) Otokar Otomativ ve Savunma Sanayi AŞ; 14) Pegasus Hava Taşımacılığı AŞ; 15) Sasa Polyester Sanayi AŞ; 16) Tofaş Türk Otomobil Fabrikası AŞ; 17) Tüpraş-Türkiye Petrol Rafineri AŞ; 18) Türk Hava Yolları AO; 19) Türkiye Şişe ve Cam Fabrikaları AŞ; 20) Ülker Bisküvi Sanayi AŞ; 21) Vestel Elektronik Sanayi ve Ticaret AŞ; 22) Türk Traktör ve Ziraat Makineleri AŞ; 23) Turk İlaç ve Serum Sanayi AŞ; 24) Petkim Petrokimya Holding AŞ; 25) Karsan Otomativ Sanayi ve Ticaret AŞ; 26) Ford Otomativ Sanayi AŞ; 27) Aygaz AŞ; 28) Arçelik AŞ; 29) Alarko Holding AŞ; 30) Bim Birleşik Mağazalar AŞ.

All information obtained throughout this study is primary and reflects the 2020/2021 data of these companies in their annual report or on their webpages. In this study, these thirty companies have been evaluated in the following tables in terms of whether they have managed to apply any abovementioned CSR activities in their annual report or on their webpages. The main aim of this research is to understand the implementation level of the CSR projects of corporations listed on the BIST 100.

Table 1: The Availability of the CSR Projects in Randomly Selected Companies' Annual Reports or Webpages Listed on the BIST 100

\begin{tabular}{|c|c|c|c|}
\hline The CSR Projects & \multirow{2}{*}{$\begin{array}{l}\text { Environmental } \\
\text { Matters }\end{array}$} & \multirow{2}{*}{$\begin{array}{l}\text { Employees and Social } \\
\text { Issues }\end{array}$} & \multirow{2}{*}{$\begin{array}{l}\text { Human Rights and Anti- } \\
\text { Corruption Issues }\end{array}$} \\
\hline Companies & & & \\
\hline $\begin{array}{l}\text { Anadolu Efes Biracilık ve Malt } \\
\text { Sanayi AŞ }\end{array}$ & $\checkmark$ & $\checkmark$ & $\checkmark$ \\
\hline $\begin{array}{l}\text { Brisa Bridgestone Sabancı Lastik } \\
\text { Sanayi ve Ticaret AŞ }\end{array}$ & $\checkmark$ & $\checkmark$ & $\checkmark$ \\
\hline Coca Cola İçecek AŞ & $\checkmark$ & $\checkmark$ & $\checkmark$ \\
\hline Çan2 Termik AŞ & $\checkmark$ & $\checkmark$ & $x$ \\
\hline $\begin{array}{c}\text { Çimsa Çimento Sanayi ve Ticaret } \\
\text { AŞ }\end{array}$ & $\checkmark$ & $s$ & $\checkmark$ \\
\hline Enka İnşaat ve Sanayi AŞ & $\checkmark$ & $\checkmark$ & $\checkmark$ \\
\hline Ereğli Demir Çelik Fabrikaları TAŞ & $\checkmark$ & $\checkmark$ & $\checkmark$ \\
\hline Gübre Fabrikaları TAŞ & $\checkmark$ & $\checkmark$ & $\times$ \\
\hline İskenderun Demir Çelik AŞ & $\checkmark$ & $\checkmark$ & $\checkmark$ \\
\hline
\end{tabular}


M. Sönmez 13/4 (2021) 3622-3634

\begin{tabular}{|c|c|c|c|}
\hline Koç Holding AŞ & $\checkmark$ & $\checkmark$ & $\checkmark$ \\
\hline Koza Altın İşletmeleri AŞ & $\checkmark$ & $\checkmark$ & $x$ \\
\hline Mavi Giyim Sanayi ve Ticaret AŞ & $\checkmark$ & $\checkmark$ & $\checkmark$ \\
\hline $\begin{array}{c}\text { Otokar Otomativ ve Savunma } \\
\text { Sanayi AŞ }\end{array}$ & $\checkmark$ & $\checkmark$ & $\checkmark$ \\
\hline Pegasus Hava Taşımacılığı AŞ & $\checkmark$ & $\checkmark$ & $\checkmark$ \\
\hline Sasa Polyester Sanayi AŞ & $\checkmark$ & $\checkmark$ & $\checkmark$ \\
\hline Tofaş Türk Otomobil Fabrikası AŞ & $\checkmark$ & $\checkmark$ & $\checkmark$ \\
\hline Tüpraş-Türkiye Petrol Rafineri AŞ & $\checkmark$ & $\checkmark$ & $\checkmark$ \\
\hline Türk Hava Yolları AO & $\checkmark$ & $\checkmark$ & $\checkmark$ \\
\hline $\begin{array}{c}\text { Türkiye Şişe ve Cam Fabrikaları } \\
\text { AŞ }\end{array}$ & $s$ & $\checkmark$ & $\checkmark$ \\
\hline Ülker Bisküvi Sanayi AŞ & $\checkmark$ & $\checkmark$ & $\checkmark$ \\
\hline $\begin{array}{l}\text { Vestel Elektronik Sanayi ve Ticaret } \\
\text { AŞ }\end{array}$ & $\checkmark$ & $\checkmark$ & $\checkmark$ \\
\hline $\begin{array}{c}\text { Türk Traktör ve Ziraat Makineleri } \\
\text { AŞ }\end{array}$ & $\checkmark$ & $\checkmark$ & $\checkmark$ \\
\hline Turk İlaç ve Serum Sanayi AŞ & $\checkmark$ & $\checkmark$ & $\times$ \\
\hline Petkim Petrokimya Holding AŞ & $\checkmark$ & $\checkmark$ & $\checkmark$ \\
\hline $\begin{array}{c}\text { Karsan Otomativ Sanayi ve Ticaret } \\
\text { AŞ }\end{array}$ & $\checkmark$ & $\checkmark$ & $\checkmark$ \\
\hline Ford Otomativ Sanayi AŞ & $\checkmark$ & $\checkmark$ & $\checkmark$ \\
\hline Aygaz AŞ & $\checkmark$ & $\checkmark$ & $\checkmark$ \\
\hline Arçelik AŞ & $\checkmark$ & $\checkmark$ & $\checkmark$ \\
\hline Alarko Holding AŞ & $\checkmark$ & $\checkmark$ & $\checkmark$ \\
\hline Bim Birleşik Mağazalar AŞ & $\checkmark$ & $\checkmark$ & $\checkmark$ \\
\hline $\begin{array}{c}\text { Total Percentage of the Availability } \\
\text { of the CRS Projects }\end{array}$ & $100 \%$ & $100 \%$ & $86,6 \%$ \\
\hline
\end{tabular}

\subsection{Analysis and Discussion}

This Table 1 aims to indicate the availability of three types of the CSR Projects: 'environmental matters, employees and social issues, and human rights and anti-corruption issues', on the webpages or in the annual reports/sustainability reports of a total of 30 randomly selected companies listed on the BIST 100. 
The evidence of this research indicates that the availability of the CSR projects of the sample corporations seems to reach an adequate level on the BIST 100. Despite the fact that there are no any legal requirements for corporations to apply the CSR projects, listed companies on the BIST 100 appear to understand the real benefits of becoming socially responsible to the all stakeholders.

According to the results of Table 1, all sample companies are successful in applying environmental matters, and employees and social issues as the CSR projects. However, in terms of human rights and anti-corruption issues, it seems that the selected companies have a problem applying or making them available on their webpages or in their annual/sustainability reports. As observed from Table 1, the total percentage of the availability of these CSR projects is $86,6 \%$ for the selected companies. It can be challenging for the listed companies on the BIST 100, because Turkey seems to lose its trustworthiness in the eye of the international investors day by day. Transparency International's 2020 Corruption Perception Index ranks Turkey $86^{\text {th }}$ place out of 180 countries (Transparency International-2020CPI). In this respect, in order to make the listed companies more attractive for long-term investors, it is essential to take further steps with regards to human rights and anti-corruption issues. Hence, all investors would have a clear picture about companies and financial markets in Turkey.

Overall, it can be claimed that the application process of the CSR projects seems to reach a satisfactory level for listed companies on the BIST 100. The empirical work above indicated that all corporations are successful in carrying out environmental matters, and employees and social issues. However, the points to take into consideration are the availability of human rights and anti-corruption issues because this type of the CSR projects seems to be problematic for the selected corporations. Trust can be accepted as the fundamental element for the attractiveness of corporations, because its absence lowers the number of investors. Therefore, the emphasis on human rights and anti-corruption issues may build trust and provide confidence in favour of corporations.

\section{Discussions and Conclusion}

The CSR can be accepted as the sense of responsibility that all undertakings should have in order to make positive contributions to the society. In this study, the advantages and disadvantages of CSR have been disgusted and how the idea of CSR has been converted into practice has been evaluated by making an empirical research in randomly selected companies on the BIST 100.

Within the framework of the findings, the advantages of the CSR can be listed as follows: to have a positive impact on increasing the profitability of corporations; to support marketing goals and to improve brand image of corporations by creating a social impact and providing prestige awards; to have positive effects on corporate image and employee motivation; to create a better financial environment based on the principle of goodwill; and so to make corporations more attractive for the long-term investors.

On the other hand, this study indicates that the CSR has also some side effects for corporations. The additional costs of the CSR; difficulties in implementing the CRS projects in markets where the competition is low; the negative views against the CSR projects that accept it as an immoral activity; the misleading impact of the CSR according to the devil side of corporations and to make a distinction between making profits and social, environmental and ethical issues can be highlighted as the outstanding disadvantages of the CSR.

This research implies that in the light of the advantages of the CSR, these disadvantages can be carried out to bearable dimensions. Fundamentally, the CSR increases the number of long-term investors in financial markets, improves the quality of products and services in corporations, and helps to reduce social, environmental, ethical problems in society. In this respect, the CSR can be considered as an effective strategy to fight with the dark or devil side of corporations in the market.

In order to understand to what extent the idea of the CSR has been converted into practise, an empirical research has been applied in randomly selected companies listed on the BIST 100. The aim of this empirical research is to examine the implementation level of the CSR projects even if there is no any legal requirement in the legislative framework. The results of Table 1 above reveals that all sample companies are successful in applying environmental matters, and employees and social issues as the CSR projects. However, in terms of human rights and anti-corruption issues, only $86,6 \%$ of the selected companies have managed to make them available in their annual reports or on their webpages. 
To overall, it can be claimed that the CSR plays a key role in converting the above-mentioned negative impacts of companies into the positive effects. It basically increases the sensitivity of corporations to environmental and social issues and provides a work environment within the framework of human rights and anti-corruption policies. Therefore, it seems necessary to expand the CSR projects for a certain size of corporations in order to increase the attractiveness of financial markets. In addition, it can be useful to create a competent authority, which will be responsible for monitoring and supervising all the CSR projects. Hence, certain standards for the CSR projects can be provided in terms of environmental, social, and human rights and anti corruption issues.

\section{References}

Akmeşe, H. (2017). Muhasebede Sosyal Yaklaşımlar, Konya: Eğitim Yayınevi,

Aktan, C. C. (2011). Toplam ahlak felsefesi ve toplam ahlak yönetimi, Hukuk ve İktisat Araştırmaları Dergisi, 3 (2), 65-82,

Aktan, C. C. ve Börü, D. (2007). Kurumsal Sosyal Sorumluluk; (Kurumsal Sosyal Sorumluluk: İşletmeler ve Sosyal Sorumluluk, Editör: Coşkun Can Aktan). İstanbul: IGIAD Yayınları, 6-24,

Aydınalp, G. I. (2013). Halkla Ilişsiler Ekseninde Kurumsal Sosyal Sorumluluk, İstanbul: Nobel Akademik Yayincilik,

Boeger, N., Murray, R., and Villiers, C. (2008). Perspective on Corporate Social Responsibility, UK-Northampton USA: Edward Elgar Cheltenham,

Bonsu, S. (2019). Corporate social responsibility: Assessing the alignment of theory and practice utilizing case studies, Journal of Marketing and Management, 10 (1), 1-18,

Campbell J. L. (2007). Why Would Corporations Behave In Socially Responsible Ways? An Institutional Theory of Corporate Social Responsibility, Academy of Management Review, Vol.32 No: 3, 946-967,

Carroll, A. B. (1979). A three-dimensional conceptual model of corporate social performance, Academy of Management Review, 4 (4), 497-505,

Carroll, A. B. (1991). The pyramid of corporate social responsibility: Toward the moral management of organizational stakeholders, Business Horizons, 34 (4), 39-48,

Carroll, Archie B. (2015). Corporate social responsibility: The centerpiece of competing and complementary frameworks, Organizational Dynamics, Vol. 44, 87-96, istep?

Carroll, Archie B. (2016). Carroll's pyramis of CSR: Taking another look, International Journal of Corporate Social Responsibility, Vol.1, 1-8,

Dalyan, F. ve Gökbel, S. A. (2005). İsletmelerde sosyal sorumluluk: IMKB'de işlem gören bankaların sosyal sorumluluk faaliyetleri ile kârlılıkları arasındaki ilişki, Eskişehir: Anadolu Üniversitesi Yayınları,

Davis, K. (1960). Can business afford to ignore social responsibilities, California Management Review, 2, 70-76,

Demirtas, M. (2015). Türkiye'de yapılan kurumsal sosyal sorumluluk faaliyetlerinin uluslararası gelişmeler bağlamında degerlendirilmesi, Kurumsal Sosyal Sorumluluk ve Kurumsal İtibar (Editör: Mine Demirtaş). İstanbul: Derin Yayınları, 1-54,

Ersöz, H. Y. (2009). Kurumsal sosyal sorumluluk, İşletmelerde Iss, Etiği (Editörler: Sabri Orman ve Zeki Parlak), İstanbul: İstanbul Ticaret Odas1, Yayın No: 2009-23, 131-170,

European Commission (2001). Green Paper-Promoting a European Framework for Corporate Social Responsibility, Commission of the European Communities, https://www.europarl.europa.eu/meetdocs/committees/deve/20020122/com(2001)366 en.pdf, accessed at 17.11.2021,

Fisk, P. (2010). Sürdürülebilir Büyüme: İnsanlar, Gezegen ve Kâr (Çeviren: Eren Yıldırım). İstanbul: MediaCat Yayınları,

Fombrun, C. J., Van Riel, C. B.M. (2003). Fame and Fortune: How Successful Companies Build Winning Reputation, New York: Financial Times Prentice Hall Books,

Freeman E.R., Dmytriyev, S. (2017). Corporate Social Responsibility and Stakeholder Theory: Learning From Each Other, Emerging Issues in Management, Vol.1, 7-15, 
Friedman, M. (1970). The Social Responsibility of Business is to Increase its Profits, The New York Times Magazine, September 13,

Friedman, M. (2007). The social responsibility of business is to increase its profits, Corporate Ethics \& Corporate Governance (By Zimmerli, Walther Ch). Holzinger, M., Richter, K., Berlin, H.: SpringerVerlag, 173-178,

Gardner M., Lienin S. (2015). Impact of the EU Directive on Non-Financial Reporting, Environmental Leader, https://www.environmentalleader.com/2015/08/impact-of-the-eu-directive-on-non-financial-reporting/, accessed at 15.11.2021,

Harris, Jared D., R. Edward Freeman. (2008). The impossibility of the separation thesis: A response to Joakim Sandberg, Business Ethics Quarterly, 18 (4), 541-548,

Hetherington J.A.C. (1973). Corporate Social Responsibility Audit: A Management Tool for Survival; London; The Foundation for Business Responsibilities cited in Crowther D., Aras G. (2008). Corporate Social Responsibility, Ventus Publishing ApS, https://my.uopeople.edu/pluginfile.php/57436/mod book/chapter/121631/BUS5116.Crowther.Aras.CS

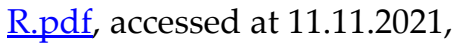

Hohnen, P. (2007). Corporate Social Responsibility: An Implementation Guide For Business (Editor: Jason Potts). Manitoba Canada: International Institute for Sustainable Development (IISD), http://www.iisd.org/pdf/2007/csr guide.pdf, accessed at 15.11.2021,

Hoştut, S., Deren van het Hof, S. (2014). Corporate social responsibility practices of transnational corporations: Examples from Turkey and Italy, European Journal of Research on Education, 2(2), 202-213, https://doi.org/10.5840/beq200818437,

Jarolimek, S. (2016). Kurumsal sosyal sorumluluk iletişiminde ölçme sorunları, (Çeviren: Seçil Deren Van Het Hof), Kurumsal Sosyal Sorumlulukta Güncel Yönelim ve Yaklaşımlar (Editörler: Sibel Hoștut ve Seçil Deren Van Het Hof). Ankara: Nobel, 117-136,

Jhawar N., Gupta S. (2017). Understanding CSR- Its History and the Recent Developments, IOSR Journal of Business and Management, Vol.19 No: 5, 105-109,

Kağınıoglu, D. (2007). Endüstri Ilişsileri Boyutuyla Sosyal Sorumluluk, Eskişehir, Anadolu Üniversitesi Yayınevi, s[s:

Kitzmueller, M., Shimshack, J. (2012). Economic Perspectives on Corporate Social Responsibility, Journal of Economic Literature, Vol.50/1, 51-84,

Koroglu, C, ve Ersoz, H. O. (2015). Muhasebe Meslek Mensuplarının Bakış Açılarından Kurumsal Sosyal Sorumluluk Muhasebe Ilișkisi, Journal Of Accounting, Finance And Auditing Studies, Volume: 1, Issue: 3, 123-153,

Kotler P., Lee, N. (2017). Kurumsal Sosyal Sorumluluk (Çeviren: Sibel Kaçamak), İstanbul: MediaCat Yayınları,

Ormiston, M.E., Wong E.M. (2013). License to ill: The Effects of Corporate Social Responsibility and CEO Moral Identity on Corporate Social Irresponsibility, Personal Psychology, 66(4), 861-893, http://dx.doi.org/10.1111/peps.12029,

Özgener, S, (2000). Ahlâk ve Sosyal Sorumluluk: İmalat Sanayinde Bir Uygulama, Doktora Tezi, Selçuk Üniversitesi Sosyal Bilimler Enstitüsü, Konya,

Öztürk, Ö. N. (2009). Kurumsal Sosyal Sorumluluğun Gelişimi ve Türkiye'de Uygulanması, Yüksek Lisans Tezi, Marmara Üniversitesi Sosyal Bilimler Enstitüsü, Istanbul,

Peltekoglu, F. B. (2014). Halkla Ilişsiler Nedir?, 8.Baskı, İstanbul: Beta Basım Yayım,

Roberts, P. W., Dowling, G. R. (2002). Corporate reputation and sustained superior financial performance, Strategic Management Journal, 23, 1077-1093,

Saxton, M. K. (1998). Where do reputation come from?, Corporate Reputation Review, 1 (4), 393-399,

Tak, B. (2009). İşletmelerin Sosyal Sorumlulukları ve Paydaș, Grupları ile Ilișkilerinin Yönetimi, İstanbul: Beta,

Tasslıyan, M. (2012). Kurumsal sosyal sorumluluk: Modern is, dünyasının vicdani gereği, Ankara Sanayi Odası Yayın Organı, Mayıs-Haziran, 22-42,

Transparency International (2020). Corruption Perceptions Index 2020, 
M. Sönmez 13/4 (2021) 3622-3634

https://www.transparency.org/en/cpi/2020/index/nzl, accessed at 20.11.2021,

Vural, A. B., Coşkun, G. (2011). Kurumsal Sosyal Sorumluluk ve Etik, Gümüşhane Üniversitesi İletişim Fakültesi Elektronik Dergisi (e-gifder), S.1, 61-87,

World Business Council for Sustainable Development (1999). CSR definition, http://www.wbcsd.org/workprogram/business-role/previous-work/corporate-social-responsibility.aspx, accessed at 17.11.2021. 